\title{
GOLDEN-THOMPSON TYPE INEQUALITIES RELATED TO A GEOMETRIC MEAN VIA SPECHT'S RATIO
}

\author{
Masatoshi FuJII, YuKi SEO AND MASARU TOMINAGA
}

Abstract. We prove a Golden-Thompson type inequality via Specht's ratio: Let $H$ and $K$ be selfadjoint operators on a Hilbert space $H$ satisfying $M I \geqslant H, K \geqslant m I$ for some scalar $M>m$. Then

$M_{h}(1)\left((1-\lambda) e^{t H}+\lambda e^{t K}\right)^{\frac{1}{t}} \geqslant e^{(1-\lambda) H+\lambda K} \geqslant M_{h}(1)^{-1} M_{h}(t)^{-\frac{1}{t}}\left((1-\lambda) e^{t H}+\lambda e^{t K}\right)^{\frac{1}{t}}$

holds for all $t>0$ and $0 \leqslant \lambda \leqslant 1$, where $h=e^{M-m}$ and (generalized) Specht's ratio $M_{h}(t)$ is defined for $h>0$ as

$$
M_{h}(t)=\frac{\left(h^{t}-1\right) h^{\frac{t}{h^{t}-1}}}{e \log h^{t}} \quad(h \neq 1) \quad \text { and } \quad M_{1}(1)=1 .
$$

Mathematics subject classification (2000): 47A30, 47A63.

Key words and phrases: operator inequality, Specht's ratio, Kantorovich type inequality, positive operator, Golden-Thompson inequality.

\section{REFERENCES}

[1] T. ANDO AND F. HIAI, Log-majorization and complementary Golden-Thompson type inequalities, Linear Algebra Appl., 197, 198 (1994), 113-131.

[2] J. I. FuJII, S. IZUMINO AND Y. SEO, Determinant for positive operators and Specht's theorem, Sci. Math., 1 (1998), 307-310.

[3] M. FujII And R. NAKAmoto, A geometric mean in the Furuta inequality, Sci. Math. Japon., to appear.

[4] T. FURUTA, Extensions of Mond-Pečarić generalization of Kantorovich inequality, preprint.

[5] T. FURUTA, Operator inequalities associated with Hölder-McCarthy and Kantorovich inequalities, J. Inequal. Appl., 2 (1998), 137-148.

[6] S. GoldEN, Lower bounds for Helmholtz function, Phys. Rev., 137 (1965), B1127-B1128.

[7] F. HiAI AND D. PETZ, The Golden-Thompson trace inequality is complemented, Linear Algebra Appl., 181 (1993), 153-185.

[8] J. Mićić, Y. SEO, S.-E. TAKAHASI AND M. TOMINAGA, Inequalities of Furuta and Mond-Pečarić, Math. Ineq. Appl., 2 (1999), 83-111.

[9] B. Mond And J. E. PEČArIĆ, Convex inequalities in Hilbert spaces, Houston J. Math., 19 (1993), 405-420.

[10] W. SPEChT, Zur Theorie der elementaren Mittel, Math. Z., 74 (1960), 91-98.

[11] K. SymanZIK, Proof and refinements of an inequality of Feynman, J. Math. Phys., 6 (1965), 1155-1156.

[12] C. J. THOMPSON, Inequality with applications in statistical mechanics, J. Math. Phys., 6 (1965), 469-480.

[13] M. Tominaga, Specht's ratio in the Young inequality, Sci. Math. Japon., 55 (2002), 583-588.

[14] M. TominaGA, Specht's ratio and logarithmic mean in the Young inequality, preprint.

[15] A. M. TURING, Rounding off-errors in matrix processes, Quart. J. Mech. Appl. Math., 1 (1948), $287-308$.

[16] T. YAMAZAKI AND M. YANAGIDA, Characterizations of chaotic order associated with Kantorovich inequality, Sci. Math., 2 (1999), 37-50. 